\title{
Potent antiretroviral treatment of HIV-infection results in suppression of the seminal shedding of HIV
}

\author{
Pietro L. Vernazza ${ }^{a, b}$, Luigi Troiani ${ }^{d}$, Markus J. Flepp ${ }^{\mathrm{e}}$, \\ Richard W. Cone ${ }^{\mathrm{e}}$, Jody Schock ${ }^{\mathrm{c}}$, Felix Roth ${ }^{\mathrm{b}}$, Katia Boggian ${ }^{\mathrm{a}}$, \\ Myron S. Cohen ${ }^{\mathrm{d}}$, Susan A. Fiscus ${ }^{\mathrm{c}}$, Joseph J. Eron ${ }^{\mathrm{d}}$ \\ and the Swiss HIV Cohort Study*
}

\begin{abstract}
Objective: The amount of HIV in semen likely influences infectiousness. Antiretroviral therapy decreases HIV-RNA in semen, but data on HIV concentrations in semen in a large cohort of men with suppressed HIV-RNA in blood is unavailable.

Methods: Male patients with a treatment-induced reduction of HIV-RNA load in plasma below 400 copies $/ \mathrm{ml}$ were asked to donate a semen and blood sample. Blood and seminal plasma were tested for the presence of HIV-RNA by the NucliSens method (detection limit 400 copies/ml). Seminal cell samples from 67 patients were further analysed for the presence of HIV-DNA using a nested DNA-polymerase chain reaction. Results of RNA and DNA testing in semen were compared with 55 HIVpositive antiretroviral therapy-naive men.

Results: A total of 114 patients participated in the study. Seminal plasma HIV-RNA was detectable in only two patients $[1.8 \%, 95 \%$ confidence ratio $(\mathrm{Cl}), 0-4.2 \%$ ] compared with a detection frequency of $67 \%$ in untreated controls [Odds ratio $(\mathrm{OR})$, $0.01 ; 95 \% \mathrm{Cl}, 0-0.03]$. Detection of cell-associated HIV-DNA in semen was significantly less frequent (16 versus $38 \%$ ) in patients receiving suppressive therapy compared with untreated controls (OR, 0.32; 95\% Cl, 0.12-0.80).

Conclusion: In patients with treatment-induced suppression of blood viral load the likelihood of having detectable HIV in semen is very low $(<4 \%)$. In addition, seminal shedding of cell-free and cell-associated HIV is significantly lower than in an untreated population of HIV-infected asymptomatic men. On a population basis, this effect of therapy may help to reduce sexual transmission of HIV. However, individual patients may still be infected as evidenced by continued shedding of cells harbouring the HIV provirus.

(c) 2000 Lippincott Williams \& Wilkins
\end{abstract}

AIDS 2000, 14:117-121

Keywords: heterosexual transmission, semen, antiretroviral therapy, viral load

\section{Introduction}

Potent antiretroviral therapy of HIV infection results in a marked suppression of HIV-RNA concentration in the blood of infected individuals. This effect of therapy is also associated with a significant increase in CD4 count, CD4 cell function and a reduction in mortality [1]. In a substantial fraction of patients receiving triple

From the ${ }^{a}$ Department of Medicine and ${ }^{b}$ Institute for Clinical Microbiology and Immunology, Kantonsspital St. Gallen, Switzerland, the ${ }^{\mathrm{C}}$ Department of Microbiology and d Division of Infectious Diseases, University of North Carolina, Chapel Hill, North Carolina, USA, e Division of Infectious Diseases and Hospital Epidemiology, University Hospital Zurich, Switzerland. * See Appendix.

Sponsorship: This work was supported by grants of the Swiss Science Foundation (3233-48902.96/ 3200-49139.96), by the Swiss HIV Cohort Study (3600.010.1), by NIH grants R0149381, UNC ACTG contracts AI25868, 96VC006, 96VD006 and RR00046, UNC-CFAR NIH-P30-HD37260 and by an unrestricted Merck medical grant.

Correspondence to Pietro L. Vernazza, Department of Medicine, KSSG, 9007 St. Gallen, Switzerland.

Tel: +4171 494 2631; fax: +4171 494 6114; email: Pietro.Vernazza@kssg.ch

Received: 9 February 1999; revised: 16 September 1999; accepted: 25 September 1999. 
drug combination, HIV-RNA can no longer be detected in blood, even with the use of highly sensitive polymerase chain reaction (PCR) technology. Recent work indicates that treatment results in a comparably potent suppression of HIV-RNA in the lymphoid tissue although the effect of highly suppressive therapy in other biological compartments is also important [2-4].

The amount of shedding of HIV-RNA in the seminal plasma is likely to correlate with the degree of infectiousness of an individual [5]. However, whether potent antiretroviral therapy is associated with a reduction of the infectiousness of treated individuals is not known. We and others have demonstrated a significant reduction of the HIV-RNA concentration in the seminal plasma of patients treated with antiretrovirals [6-9]. However, these studies involved small numbers of patients, and some of the patients were not treated with highly active drug combinations. Recent reports comparing sequences in viral isolates obtained from blood and semen indicate that HIV may be compartmentalized in the genital tract, and semen may serve as a sanctuary site for residual HIV infection, even with use of potent antiretroviral treatment [10-13]. Thus, it is conceivable that continuous HIV-1 replication in the genital tract might occur even in the face of HIV suppression in the systemic compartment. Previous studies have been too small to exclude with any certainty that a substantial minority of men who have HIV RNA below detectable limits in the blood will have persistent HIV shedding in semen. In the context of transmission, future studies will also have to focus more on HIV-infected cells in the genital tract. The aim of this study was to investigate the frequency of residual HIV-replication in the genital tract in a large number of men whose HIV-RNA levels are below detectable limits in blood.

\section{Methods}

\section{Study design and patient selection}

This study was conducted in three HIV clinics at the University of Zürich and at the Kantonsspital St. Gallen, Switzerland and at the University of North Carolina at Chapel Hill, North Carolina, USA. All HIV-infected men who donated a semen sample at one of the three institutions while receiving antiretroviral treatment were selected as cases if their blood viral load was suppressed below 400 copies/ml (NucliSens, Organon Teknika, Boxtel, The Netherlands). In patients with detectable HIV-RNA in semen, blood plasma was further tested with a more sensitive PCR assay (lower limit $=20$ copies $/ \mathrm{ml}$ [14]. A group of drugnaive, HIV-positive men from one centre (St. Gallen) was also studied to provide a comparison. This popula- tion was an unselected, unmatched, consecutive group of HIV-positive men with a median CD4 count of $280 \times 10^{6}$ cells $/ 1$ who were asked to give a semen and blood specimen. None of the subjects had symptoms of urethritis. All samples were frozen until tested by PCR in the same series of experiments.

\section{HIV detection in semen}

Detection of HIV-RNA in seminal plasma was quantified by NucliSens technology. Seminal plasma was separated from seminal cells by centrifugation $(10 \mathrm{~min}$ at $1000 \mathrm{~g}$ ) and frozen within $4 \mathrm{~h}$ of ejaculation. Two hundred microlitres of seminal plasma was used per assay (detection limit: 400 copies $/ \mathrm{ml}$ ). In the samples from the two Swiss centres seminal cells were washed twice after separation of seminal plasma, and an equivalent of one-sixth of the ejaculate was used to detect HIV-DNA by nested PCR. The DNA-extraction was performed using the QIAamp spin column procedure (Qiagen, Basel, Switzerland) and one-sixth of the extracted DNA was tested with nested HIV PCR using gag-based primer pairs.

\section{Statistical methods}

Results of RNA and DNA testing in semen from treated men were compared with the results in the historical control by $\chi^{2}$ (Yates corrected). The Kruskal-Wallis test was used to compare the median duration of HIV-RNA suppression in blood in the patients with and without detectable HIV-DNA in semen.

\section{Results}

One hundred and fourteen patients on therapy with an HIV-RNA concentration below 400 copies $/ \mathrm{ml}$ of blood were enrolled (Zürich, $\mathrm{n}=28$; St. Gallen: $\mathrm{n}=45$, Chapel Hill: $\mathrm{n}=41$ ). Treatment consisted of a triple combination of two nucleoside RT-inhibitors with a protease inhibitor or nevirapine in 97 patients (14 nelfinavir; 55 indinavir; 23 ritonavir $+/-$ saquinavir; four saquinavir; one nevirapine). One patient was receiving didanosine + hydroxyurea, one patient was on zidovudine + lamivudine + abacavir and 15 patients had a combination therapy with two reverse transcriptase (RT)-inhibitors. The median time of suppressed HIV-RNA in blood below 400 copies/ml was 7.2 months (range, 0-19.3). For comparison, HIV was measured in the semen of 55 drug-naive HIV-positive men. The median concentration of HIV-RNA in blood of these untreated men was $4.8 \log _{10}$ copies $/ \mathrm{ml}$.

HIV-RNA in seminal plasma was detected in only two of the 114 men [1.8\%; 95\% confidence interval (CI), $0-4.2 \%$ ]. The detection frequency was $67 \%$ (36 of 55 ) in the group of untreated men. [odds ratio (OR), 0.01; 95\% CI, $0-0.03 ; P<0.0001$, Fig. 1). The treatment 


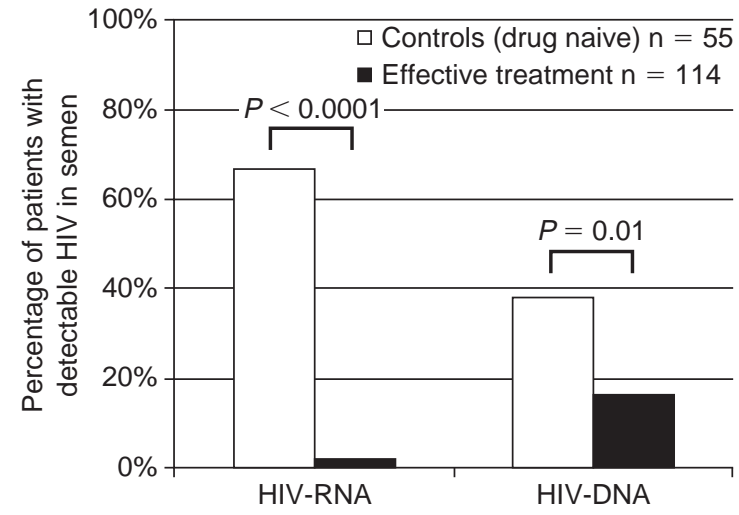

Fig. 1. Detection rate of HIV in semen. Detection rates of cell-free and cell-associated HIV in drug naïve historical controls (white) and treated individuals (black) in seminal plasma (HIV-RNA) and seminal cells (HIV-DNA). Seminal cells were only analysed in a subgroup of men from one centre.

regimen, duration of therapy and HIV-RNA levels in blood and semen of the two men who had detectable virus in semen despite blood level $<400$ copies $/ \mathrm{ml}$ are shown in Table 1 . When the blood of these two patients was re-tested by ultrasensitive PCR, the HIVRNA concentrations were 2.5 and $2.2 \log _{10}$ copies $/ \mathrm{ml}$. Baseline samples (at the start of antiretroviral therapy) were available for these two patients. One man had a very high seminal viral load at the start of treatment, 2 $\log _{10}$ copies $/ \mathrm{ml}$ above the value in blood. In the 55 treatment-naïve men, the HIV-RNA concentration was generally lower in semen than in blood with a median difference of $0.9 \log _{10}$ copies $/ \mathrm{ml}$.

Seminal cells were available from a subgroup of 67 patients for HIV-DNA testing. Detection of cellassociated HIV-DNA in semen was significantly less frequent in patients receiving potent therapy compared with untreated individuals (11 of $67=16 \%$ versus 21 of $55=38 \% ; \quad$ OR, $0.32 ; \quad 95 \% \quad$ CI,$\quad 0.12-0.80$; $P=0.01)$. Cases with detectable HIV-DNA in semen had a shorter duration of therapy (median 5.3 months below detection level) in comparison with the cases with negative HIV-DNA detection in semen (median 9.2 months, $P=0.09$ ).

\section{Discussion}

The purpose of this study was to determine the proportion of men with treatment-induced suppression of HIV-RNA $<400$ copies/ml of blood who continued to have detectable HIV-RNA in seminal plasma. Such men, even if present in a substantial minority, may not have been detected in earlier small studies. A cut-off of 400 copies/ $\mathrm{ml}$ was selected because lower detection levels have not been consistently achieved due to inhibitors present in semen [15].

In this large study, only two of 114 treated subjects with HIV-RNA $<400$ copies/ml of blood had detectable HIV-RNA in the seminal plasma. In fact, all 97 men who were receiving at least three-drug therapy, which included a potent protease inhibitor or nevirapine, were below 400 copies $/ \mathrm{ml}$ of semen. Given the size of our study, we can say with $95 \%$ confidence that in treated patients with a blood viral load below 400 copies/ml the proportion of men with detectable HIV-RNA in semen would not be greater than $4.2 \%$ in similar populations. As a point of reference, a group of previously studied drug-naïve asymptomatic, HIVpositive men were also studied. Seminal shedding in this group was by far more frequent (67 versus $1.8 \%$ ) than in the study group but similar to previously reported studies of asymptomatic drug-naïve men $[16,17]$.

The seminal HIV-RNA levels in the two subjects above the 400 copies $/ \mathrm{ml}$ cut-off value were only slightly above the limit of detection of the assay and only marginally above the concentration found in the blood. In fact, the drug combinations used in these two patients are currently not recommended as highly potent antiretroviral drug combinations [18]. One of these men had substantially higher HIV RNA in semen than in blood prior to therapy. In men who demonstrate this phenomenon, suppression of HIV in the genital tract may be more difficult [19] and they may be at greater risk of shedding resistant virus [12].

Even under optimal conditions, recovery rates of replicating virus from seminal plasma are low [20].

Table 1. Summary of two patients with detectable HIV-RNA in semen under suppressive antiretroviral therapy.

\begin{tabular}{lclll}
\hline & Week of & \multicolumn{2}{c}{ HIV-RNA $^{\mathrm{a}}$} & \\
\cline { 3 - 4 } & therapy & \multicolumn{1}{c}{ Blood } & \multicolumn{1}{c}{ Semen } & Treatment \\
\hline Patient 1 & 0 & $3.4(2500)$ & $5.4\left(2.5 \times 10^{5}\right)$ & DDI + HU \\
& 8 & $2.5^{\mathrm{b}}(300)$ & $3.0(1000)$ & \\
Patient 2 & 0 & $4.5^{\mathrm{b}}(30000)$ & $3.0(1000)$ & ZDV + DDC + SQV \\
& 7 & $2.2^{\mathrm{b}}(160)$ & $2.8(630)$ & \\
\hline
\end{tabular}

\footnotetext{
${ }^{\mathrm{a}} \log _{10}($ copies $/ \mathrm{ml})$.

${ }^{b}$ Measured by ultrasensitive RNA-PCR, was negative by NucliSens (detection limit 2.6).

DDI, didanosine; HU, hydroxyurea; ZDV, zidovudine; DDC, zalzitabine; SQV, saquinavir.
} 
Therefore, we and others have focused primarily on detection of HIV RNA in seminal plasma, as a reflection of viral burden [15-17]. Although vaginal transmission of simian immune-deficiency virus (SIV) is much easier by cell-free than cell-associated virus [21], it still remains uncertain, whether cell-associated HIV is an important vehicle for the sexual transmission of HIV. HIV can be isolated in vitro from seminal cells [22-24] and viral growth directly correlates with HIVDNA detection in seminal cells [25].

In this study, we chose to assay for the presence of HIV-DNA in seminal cells. Detection of HIV DNA was significantly lower in treated patients when compared with the untreated men. However, HIV DNA was still detectable in a substantial proportion of men with HIV RNA $<400$ copies $/ \mathrm{ml}$ in blood. Although the significant difference of DNA detection in treated and untreated individuals and the decreasing likelihood of DNA detection with time on effective therapy are reassuring; the DNA assay used in this study was not quantitative and has limited sensitivity. Zhang et al. demonstrated the preservation of replication-competent HIV in seminal cells from three of seven men on highly active antiretroviral therapy (HAART) [9]. Intuitively, one would expect that treatment-associated reduction of HIV-DNA in semen results from suppression of HIV replication and that the number of infected cells would decrease over time. However, the effect of HAART on HIV-DNA shedding and the presence of infected cells in semen must be further evaluated in large longitudinal studies. It remains to be determined whether replication-competent HIV can be completely and permanently eradicated from the semen of patients on prolonged therapy, so as to eliminate this as a viral reservoir. Furthermore, the kinetics of the infected cell turnover and the presence of latently infected lymphocytes in the genital tract are unknown.

Sexual transmission of HIV almost certainly relates to the concentration of HIV in semen, as documented for transmission by all other routes [5]. HAART is now recommended for most patients with HIV infection, and the majority of patients have an excellent therapeutic response, with blood viral burden suppressed below detection with our most sensitive tests [14]. In this study we demonstrated with confidence that less than $4.2 \%$ of men on HAART who have HIV RNA below detectable levels in blood are likely to have detectable virus in semen. Absence of detectable HIV-RNA in semen certainly does not prove that such patients cannot transmit HIV. Indeed, we do not know the relative importance of cell-free and cell-associated virus for the sexual transmission of HIV, and we have emphasized the recovery of HIV DNA from seminal cells in some patients in whom no HIV-RNA is detected in blood and seminal plasma. Even if HIVRNA is completely absent in semen, patients can still sexually transmit cells that contain the provirus. However, suppression of HIV in semen seems highly desirable, and ongoing biological and epidemiological studies should help to determine whether HAART reduces transmission of HIV within a population.

\section{References}

1. Egger $M$, Hirschel B, Francioli $P$, Sudre $P$, Wirz $M$, Flepp $M$, et al. Impact of new antiretroviral combination therapies in HIV infected patients in Switzerland: prospective multicentre study. Swiss HIV Cohort Study. BMJ 1997, 315:1194-1199.

2. Cavert W, Notermans DW, Staskus K, Wietgrefe SW, Zupancic M, Gebhard $\mathrm{K}$, et al. Kinetics of response in lymphoid tissues to antiretroviral therapy of HIV-1 infection. Science 1997, 276:960-964.

3. Mayers D, Bethel J, Wainberg MA, Weislow O, Schnittman S, Div AIDS Treat Res Init. Human immunodeficiency virus proviral DNA from peripheral blood and lymph nodes demonstrates concordant resistance mutations to zidovudine (codon 215) and didanosine (codon 74). J Infect Dis 1998, 177:1730-1733.

4. Perrin L, Yerly S, Marchal F, Schockmel GA, Hirschel B, Fox CH, et al. Virus burden in lymph nodes and blood of subjects with primary human immunodeficiency virus type 1 infection on bitherapy. J Infect Dis 1998, 177:1497-1501.

5. Vernazza PL, Eron JJ, Fiscus SA, Cohen MS. Sexual transmission of HIV: Infectiousness and prevention. AIDS 1999, 13: 155-166.

6. Gilliam BL, Dyer JR, Fiscus SA, Marcus C, Zhou S, Wathen L, et al. Effects of reverse transcriptase inhibitor therapy on the HIV-1 viral burden in semen. J Acquir Immune Defic Syndr Hum Retrovirol 1997, 15:54-60.

7. Vernazza PL, Gilliam BL, Flepp M, Dyer IR, Frank AC, Fiscus SA, et al. Effect of antiviral treatment on the shedding of HIV-1 in semen. AIDS 1997, 11:1249-1254.

8. Gupta P, Mellors J, Kingsley L, Riddler S, Singh MK, Schreiber S, et al. High viral load in semen of human immunodeficiency virus type 1-infected men at all stages of disease and its reduction by therapy with protease and nonnucleoside reverse transcriptase inhibitors. J Virol 1997, 71:6271-6275.

9. Zhang $H$, Dornadula $G$, Beumont $M$, Livornese L, Van Uitert B, Henning $\mathrm{K}$, et al. Human Immunodeficiency virus type-1 in the semen of men receiving highly active antiretroviral therapy. $\mathrm{N}$ Engl J Med 1998, 339:1803-1809.

10. Byrn RA, Zhang DZ, Eyre R, McGowan K, Kiessling AA. HIV-1 in semen: an isolated virus reservoir. Lancet 1997, 350: (9085):1141-1141.

11. Delwart EL, Mullins JI, Gupta P, Learn GH, Holodniy M, Katzenstein D, et al. Human immunodeficiency virus type 1 populations in blood and semen. J Virol 1998, 72:617-623.

12. Eron JJ, Vernazza PL, Johnston DM, Seillier-Moiseiwitsch F, Alcorn TM, Fiscus SA, et al. Resistance to HIV-1 to antiretroviral agents in blood and seminal plasma: Implications for transmission. AIDS 1998, 12:F181-F189.

13. Kiessling AA, Fitzgerald LM, Zhang DZ, Chay $\mathrm{H}$, Brettier D, Eyre $\mathrm{RC}$, et al. Human immunodeficiency virus in semen arises from a genetically distinct virus reservoir. AIDS Res Hum Retro 1998, 14:S33-S41.

14. Schockmel GA, Yerly S, Perrin L. Detection of low HIV-1 RNA levels in plasma. J Acquir Immune Defic Syndr Hum Retrovirol 1997, 14:179-183.

15. Dyer JR, Gilliam BL, Eron JJ, Grosso L, Cohen MS, Fiscus SA. Quantitation of human immunodeficiency virus type 1 RNA in cell free seminal plasma: comparison of NASBA with Amplicor reverse transcription-PCR amplification and correlation with quantitative culture. J Virol Methods 1996, 60:161-170.

16. Vernazza PL, Gilliam BL, Dyer JR, Fiscus SA, Eron JJ, Frank AC, et al. Quantitation of HIV in semen: Correlation with antiviral treatment and immune status. AIDS 1997, 11:987-993.

17. Coombs RW, Speck CE, Hughes JP, Lee W, Sampoleo R, Ross SO, et al. Association between culturable human immunodeficiency virus type 1 (HIV-1) in semen and HIV-1 RNA levels in semen and blood: Evidence for compartmentalization of HIV-1 between semen and blood. J Infect Dis 1998, 177:320-330. 
18. Anderson J, Armstead R, Baker AC, Barr D, Bozzette S, Cox S, et al. Guidelines for the use of antiretroviral agents in HIV-infected adults and adolescents. Ann Intern Med 1998, 128:1079-1100.

19. Eron JJ, Smeaton L, DeGruttola V, Schock J, Fiscus S, Tung R, et al. The effects of Amprenavir (APV) alone or in combination with ZDV/3TC, on HIV-1 levels in Semen: a substudy of ACTG 347. 6th Retrovirus Conference, Chicago, Feb. 1-4, 1999 [Abstract 222]

20. Vernazza PL, Eron JJ, Fiscus SA. Sensitive method for the detection of infectious HIV in semen of seropositive individuals. J Virol Methods 1996, 56:33-40.

21. Sodora DL, Gettie A, Miller CJ, Marx PA. Vaginal transmission of SIV: Assessing infectivity and hormonal influences in macaques inoculated with cell-free and cell-associated viral stocks. AIDS Res Hum Retro 1998, 14:S119-S123.

22. Krieger JN, Coombs RW, Collier AC, Ross SO, Chaloupka K, Cummings DK, et al. Recovery of human immunodeficiency virus type 1 from semen: minimal impact of stage of infection and current antiviral chemotherapy. J Infect Dis 1991, 163: 386-388.

23. Anderson DJ, Obrien TR, Politch JA, Martinez A, Seage GR, Padian $\mathrm{N}$, et al. Effects of disease stage and zidovudine therapy on the detection of human immunodeficiency virus type-1 in semen. JAMA 1992, 267:2769-2774.

24. Vernazza PL, Eron JJ, Cohen MS, van der Horst CM, Troiani L, Fiscus SA. Detection and biologic characterization of infectious HIV-1 in semen of seropositive men. AIDS 1994, 8:1325-1329.

25. Vernazza PL, Dollenmaier G, Gowland PL, Roth F, Eron, JJ, Fiscus SA. Quantitative HIV-DNA detection in semen of HIV infected individuals: Correlation with HIV-RNA and culture. 5th Conf Retro and Opportunistic Infect, Chicago, February 1-5 1998 [Poster 190].

\section{Appendix}

The members of the Swiss HIV Cohort Study are: M. Battegay (Co-Chairman of the Scientific Board), E. Bernasconi, Ph. Bürgisser, M. Egger, P. Erb, W. Fierz, M. Flepp (Chairman of the Group Clinics), P. Francioli (President of the SHCS, Centre Hospitalier Universitaire Vaudois, CH-1011- Lausanne), H.J. Furrer, P. Grob, B. Hirschel (Chairman of the Scientific Board), B. Ledergerber, R. Malinverni, L. Matter (Chairman of the Group Laboratories), A. Meynard, M. Opravil, F. Paccaud, G. Pantaleo, L. Perrin, W. Pichler, J-C. Piffaretti, M. Rickenbach (Head of Data Center), P. Sudre, J. Schupbach, A. Telenti, P. Vernazza, R. Weber. 